bao cao su tránh thai; mong muốn có thai trong tương lai và người ảnh hưởng nhất đến quyết định phá thai là người chồng/người yêu là những yếu tố có mối liên quan có ý nghĩa thống kê đễn phá thai lặp lại của đối tượng nghiên cứu $(p<0,05)$.

\section{TÀI LIÊU THAM KHẢO}

1. Singh S., Remez L., Sedgh G. và cộng sự. (2018). Abortion Worldwide 2017: Uneven Progress and Unequal Access. .

2. Mota N.P., Burnett M., và Sareen J. (2010). Associations between abortion, mental disorders, and suicidal behaviour in a nationally representative sample, Can J Psychiatry, 55(4), 239-247.

3. Nguyển Hữu Thời N.T.T.V. Tỷ lệ và các yễu tỗ liên quan đến phá thai lặp lại ở phụ nữ trong tuổi sinh đẻ có chông tại xầ Nhơn Ai, huyện Phong Điên, thành phố Cần Tho. <https:// yhoctphcm.ump.edu.vn/index.php? Content= ChiTietBai\&idBai=6869>, accessed: 09/12/2021.

4. Vương L.H. và Thương B.C. (2018). Tỷ lệ và các yếu tố liên quan đến phá thai lặp lại ở nhửng phụ nữ tới phá thai tại bệnh viện đa khoa tỉnh đồng nai. 7.

5. Picavet C., Goenee M., và Wijsen C. (2013). Characteristics of women who have repeat abortions in the Netherlands. The European Journal of Contraception \& Reproductive Health Care, 18(5), 327-334.

6. Toprani A. (2015). Repeat Abortions in New York City, 2010. J Urban Health, 92(3), 593-603.

7. Chatterjee P. (2009). Sex ratio imbalance worsens in Vietnam. The Lancet, 374(9699), 1410.

8. Ngo T.D., Keogh S., Nguyen T.H. và cộng sự. (2014). Risk factors for repeat abortion and implications for addressing unintended pregnancy in Vietnam. International Journal of Gynecology \& Obstetrics, 125(3), 241-246.

\title{
NGHIÊN CỨU TỔNG QUAN VỀ MỐI LIÊN QUAN GIỮA GEN VÀ CÁC BÊ̂NH CHUYỂN HÓA TRÊN CO' SỞ XÉT NGHIỆM GEN CircleDNA
}

\section{Trương Hồng Sơn*, Nguyễn Xuân Ninh*, Lưu Liên Hương*, Lê Minh Khánh*}

\section{TÓM TẮT}

Gen và các bệnh chuyển hóa là một nhánh của xét nghiệm gen, nhẳm xác định vai trò của các biến thể gen đặc hiệu với các vấn đề liên quan đến chuyển hóa ví dụ như khả năng điều hòa đáp ứng với các thành phần của chế độ ăn, các kết quả của tương tác gen với chế độ ăn đển tình trạng sức khỏe và đặc biệt là khả năng mắc các bệnh liên quan đến chuyển hóa. Các nghiên cứu về Gen và các bệnh chuyển hóa trong lâm sàng đã cho thấy: (1) Các gen được chứng minh là có liên quan khá mạnh đến bệnh tiểu đường type 2 là TCF7L2, tiểu đường typ 1 là SLC30A8, (2) Các gen đã được chứng minh là có liên quan đến tất cả các chỉ số đánh giá rối loạn lipid máu, bao gồm cholesterol toàn phân, $L D L, H D L$ và triglyceride là $P C S K 9$ và $L D L R$, (3) Một số đa hình của gen FTO có thể làm tăng nguy cơ thừa cân béo phì trên nhiều đối tượng như người trưởng thành, trẻ em...Gen BDNF có ảnh hưởng đến quá trình điêu hoà cân bằng năng lượng, cũng như các cảm giác thèm ăn và các rối loạn về thần kinh liên quan, (4) Gen đã được chứng minh có liên quan đến các dạng ung thư thường gặp bao gồm gen $\mathrm{MSH} 2$ với ung thư đại trực tràng, BRCA1, BRCA2 với ung thư vú.

Tư khóa: bệnh chuyển hóa, rối loạn chuyển hóa, gen và chuyển hóa

*Viện Y học ứng dụng Việt Nam

Chịu trách nhiệm chính: Trương Hồng Sơn

Email: vienyhocungdung@gmail.com

Ngày nhận bài: 26.10.2021

Ngày phản biện khoa học: 27.12.2021

Ngày duyệt bài: 4.01.2022

\section{SUMMARY}

\section{REVIEW ABOUT THE ASSOCIATION} BETWEEN GENES AND METABOLIC

\section{DISEASES BASED ON CircleDNA TEST}

Genes and metabolic syndromes is a branch of genomic testing, to determine the role of specific gene variants with metabolism-related characteristics, including the responses to diet, and the interactions between genes and diet on health status and the risk of metabolic diseases. Studies about genes and metabolism have shown that: 1) Genes that have been shown to be strongly associated with type 2 diabetes is TCF7L2, type 1 diabetes is SLC30A8, (2) The genes have been shown to be associated with all markers of dyslipidemia, including total cholesterol, $\mathrm{LDL}, \mathrm{HDL}$, and cholesterol, triglycerides are PCSK9 and LDLR, (3) Some polymorphisms of the FTO gene can increase the risk of overweight and obesity in many subjects such as adults, children... BDNF gene affects the regulation of homeostasis. energy, as well as cravings and related neurological disturbances, (4) Genes that have been shown to be associated with common cancers include $\mathrm{MSH} 2$ gene for colorectal cancer, BRCA1, BRCA2 for breast cancer

Keyword: metabolic disease, metabolic disorders, genes, metabolism

\section{I. ĐẶT VẤN ĐỀ}

Giải mã gen là một trong những bước đột phá của nền y học hiện đại. Tính ưu việt của phương pháp giải mã gen được ứng dụng nhiều nhất trong chẩn đoán và điều trị bệnh. Giải mã gen 
giúp phát hiện ra các bệnh về di truyền, đột biến gen, rối loạn phát triển, đột biến số lượng và cấu trúc nhiễm sắc thể... phục vụ cho sàng lọc trước sinh hay tầm soát ung thư và thậm chí là tìm hiểu tiềm năng của mối người. Hiện nay, đã có nhiều đơn vị y tế triển khai lĩnh vực xét nghiệm gen, đưa xét nghiệm gen đến gần hơn với người bệnh, tuy vậy việc từ kết quả xét nghiệm gen đến việc diển giải kết quả vẫn còn nhiều khó khăn, vì mức độ hiểu biết về hoạt động tương tác đa gen và gen với môi trường đối với bác sỹ lâm sàng còn nhiều hạn chế. Đặc biệt là trong chẩn đoán các bệnh chuyển hóa, yếu tố di truyền và gen có ảnh hưởng tương đối lớn đến nhiêu khía cạnh nhưng lại chưa có tài liệu nào tổng hợp lại các thông tin này. Do đó, nghiên cứu đã được tiến hành dựa trên xét nghiệm gen của CircleDNA với mục tiêu tổng hợp về vai trò của gen và các yếu tố về di truyên đối với các bệnh chuyển hóa. Xét nghiệm gen của CircleDNA áp dụng công nghệ giải trình tự toàn bộ exome (whole exome sequencing-WES). Công nghệ này có khả năng phân tích một lượng lớn các đa hình của các gen, giúp trực tiếp phát hiện các đa hình gen liên quan đến các nguy cơ về bệnh tật, từ đó giúp phát hiện sớm và góp phần dự phòng sớm nhiều bệnh mạn tính, đặc biệt là các bệnh liên quan đến chuyển hóa.

\section{GEN VÀ BÊ̂NH TIỂU ĐƯỜNG \\ *Gen TCF7L2}

Tên đầy đư: transcription factor 7 like 2 (còn biết dưới tên TCF4; TCF-4). Vị trí: nằm trên NST số 10 , vị trí 10q25.2 - q25.3, chứa 19 exons và di truyền trội trên NST thường.

Các biến thể của gen TCF7L2 có liên quan đến bệnh tiểu đường type-2 ở nhiều nhóm chủng tộc. Các biến thể liên quan cụ thể làm tăng nguy cơ mắc bệnh tiểu đường type-2 lên 1,5 lần ở những người dị hợp tử và 2,4 lần ở những người đồng hợp tử, tương ứng với nguy cơ thuộc về quần thể là $21 \%$. Điều này làm cho các biển thể TCF7L2 trở thành yếu tố nguy cơ di truyền mạnh nhất được biết đến đối với bệnh tiểu đường type-2 [1].

TCF7L2 là một alen nguy cơ với sự hiện diện ở 36\% các cá thể bị tiểu đường type-2. Khó có thể lý giải được mối quan hệ nhân quả của gen này với nguy cơ tiểu đường, tuy nhiên người ta quan sát được ảnh hưởng của alen nguy cơ TCF7L2 đến việc tiết insulin. Cơ chế của việc này như sau: phối hợp kích thích của tế bào beta tụy: glucose, thông qua ty thể sản xuất ra ATP và tăng tỷ lệ ATP trên ADP dẫn đến kênh $\mathrm{K}^{+}$ nhậy cảm với ATP đóng lại, tạo ra điện tử hoạt động dẫn đến mở các kênh $\mathrm{Ca}^{2+}$ kích thích sự xuất bào của các túi có chứa insulin. Các túi chứa insulin khác nhau có chức năng giải phóng khác nhau, Đa phần các túi không đủ điều kiện để giải phóng chất và thuộc về nhóm được lưu trữ lại. Chỉ có một tỷ lệ nhỏ các túi được giải phóng ra ngay lập tức. Những túi này được đặt ở gần kênh $\mathrm{Ca}^{2+}$. Trong trường hợp thiếu đi TCF7L2 kênh canxi có thể tách ra khỏi các túi chứa insulin và không thể giải phóng được insulin.

\section{*Gen SLC30A8}

Tên đầy đủ: solute carrier family 30 member 8 (còn biết dưới tên ZNT8, ZnT-8). Vị trí: 8q24.11.

SLC30A8 mã hóa chất vận chuyển kẽm có giới hạn trong tuyến tụy nội tiết và thường ở túi nội tiểt là ZnT8. Sự quan tâm đến gen này đã được đề cập đến từ năm 2007 khi nghiên cứu liên kết toàn bộ bộ gen đầu tiên đối với bệnh tiểu đường type-2 xác định các đa hình của gen SLC30A8 có ảnh hưởng đến nguy cơ mắc bệnh. Đa hình rs13266634 có liên quan đến việc giảm chức năng tế bào beta và tăng $14 \%$ tỷ lệ mắc bệnh tiểu đường trên mỗi alen nguy cơ (C).

Phân tích các kiểu gen của SLC30A8 SNPs trên 847 đối tượng mắc tiểu đường type- 1 và 1021 đối tượng khỏe mạnh cho thây $82 \%$ những người khởi phát tiểu đường trước 5 tuổi có alen $C$ (alen nguy $c 00$ ), những người mang kiểu gen đồng hợp tử CC chiếm $65 \%$, so với những người khởi phát sau 5 tuổi thì người mang alen $C$ chiếm $67 \%$ và mang kiểu gen CC là $49 \%$ với $p<0,01$. Ở nhóm không bị bệnh, tỷ lệ người mang alen $C$ là $69 \%$ và $48 \%$ người có kiểu gen $C C$ với $p<0,03$. Những con số này chỉ ra rằng rối loạn chức năng tế bào, trong bệnh lý tiểu đường tự miễn có sự nhạy cảm về gen [2].

\section{GEN VÀ RỐI LOẠN LIPID MÁU \\ *Gen PCSK9}

Tên đầy đủ: proprotein convertase subtilisin/kexin type 9 (còn biết dưới tên FH3; PC9; FHCL3; NARC1; LDLCQ1; NARC-1; HCHOLA3). Vị trí: nằm trên NST số 1 ở vị trí $1 \mathrm{p} 32.3$ và bao gồm 13 exons

Các nhà nghiên cứu đã xác định được hơn 50 đột biến gen PCSK9 gây tăng cholesterol máu có tính chất chất di truyền. Hầu hết các đột biến này làm thay đổi các acid amin trong protein PCSK9. Các nhà nghiên cứu mô tả các đột biến gây tăng cholesterol máu di truyền là "tăng chức năng" vì chúng dường như tăng cường hoạt động của protein PCSK9. Protein PCSK9 tăng hoạt động sẽ khiến các thụ thể LDL bị phá huỷ 
nhanh hơn bình thường, dẫn đến giảm số lượng thụ thể $L D L$ trên bề mặt tế bào gan. Khi có ít thụ thể để loại bỏ LDL từ máu, thì những người có đột biến gen PCSK9 sẽ có lượng cholesterol trong máu rất cao. Khi lượng cholesterol trong máu quá cao, cholesterol sẽ lắng đọng trong các mô ví dụ như da, gân, và các động mạch cấp máu đến tim (mạch vành). Tích tụ cholesterol ở thành mạch vành làm tăng đáng kể nguy cơ nhồi máu cơ tim.

Đa số những người bị tăng cholesterol di truyền đều có một gen PCSK9 bị đột biến từ cha/me và một gen PCSK9 bình thường từ cha/mẹ. Những trường hợp này thường có nguy cơ bị bệnh tim mạch tăng đáng kể, đặc biệt là khi ở độ tuổi 40 hoặc 50 . Rất hiếm khi, những người bị tăng cholesterol di truyền sẽ có cả 2 gen đột biến. Trường hợp này chỉ xảy ra khi người bệnh có cha/mẹ mà mỗi người đều có bộ gen có chứa một gen bị đột biến. Những người có cả 2 gen đột biển thường sẽ bi tăng cholesterol ở dạng nặng hơn và thường xuất hiện ngay từ khi còn nhỏ.

\section{*Gen LDLR}

Tên đây đủ: low density lipoprotein receptor (còn biết dưới tên FH; FHC; FHCL1; LDLCQ2). Vị trí: 19p13.2. Loại gen: mã hóa protein [3].

Gen LDLR nằm trên NST số 19 ở dải 19p13.2 và được tách thành 18 exons.

Sự thay đổi vị trí LDLR ảnh hưởng đến LDLcholesterol trong dân số nói chung. Đột biến LDLR nghiêm trọng là nguyên nhân gây ra tăng cholesterol máu gia đình.

Nghiên cứu trên quần thể người Hán ở Trung Quốc cho thấy 2 đa hình của gen LDLR là đa hình rs1003723 và rs6413504 có mối liên kết chă̆t chẽ với nồng độ cholesterol toàn phần, 2 đa hình rs1003723 và rs6413504 có liên quan đến lượng LDL cholesterol, 2 đa hình rs662145 của gen PCSK9 và rs1163718 của gen SLC12A3 có liên quan đến hàm lượng triglyceride trong máu. Khi kết hợp lại với nhau, những đa hình này sẽ có ảnh hưởng rất lớn đến chỉ số lipid máu: cholesterol toàn phần tăng $0.085 \mathrm{mmol} / \mathrm{L}$, LDL tăng $0.075 \mathrm{mmol} / \mathrm{L}$ và triglyceride tăng 0.096 $\mathrm{mmol} / \mathrm{L}$. So với những người không mang alen nguy cơ, thì nguy cơ tăng triglyceride, tăng cholesterol và rối loạn lipid máu ở những người có trên 2 alen nguy cơ hoặc 1 gen nguy cơ sẽ cao hơn nhiều [4]

\section{GEN VÀ NGUY CƠ BÉO PHI}

Thừa cân được định nghĩa là khi chỉ số khối cơ thể trên 25 và béo phì là khi chỉ số khối cơ thể trên 30. Mặc dù các yếu tố môi trường chẳng hạn như ít hoạt động thể chất và ăn quá nhiều đã thúc đẩy sự gia tăng số lượng người béo phì, nhưng các yếu tố di truyền cũ̃ng có những tác động nhất định và các yếu tố di truyên ước tính gây ra từ 40-90\% sự biến đổi BMI trong quần thể. Thừa cân béo phì là một yếu tố nguy cơ quan trọng của nhiều bệnh chuyển hóa như tiểu đường, tăng huyết áp, ung thư...

\section{${ }^{*}$ Gen FTO}

Tên đầy đư: FTO alpha-ketoglutarate dependent dioxygenase (còn biết dưới tên GDFD; ALKBH9; BMIQ14). Vị trí: 16q12.2.

Kế từ khi những kết quả đầu tiên được công bố năm 2007, mối liên quan giữa gen FTO và tình trạng thừa cân béo phì đã thường xuyên được xác nhận lại thông qua nhiều nghiên cứu trên nhiều cộng đồng người khác nhau. Tuy nhiên, ảnh hưởng của "alen nguy cơ" với những người mang gen khá nhỏ. Mối phiên bản copy của alen nguy cơ cho thây việc tăng khoảng 4 $\mathrm{kg} / \mathrm{m} 2$ chỉ số BMI. Mặc dù mối liên hệ này chỉ đúng đối với trẻ trên 5,5 tuổi, người trưởng thành và người cao tuổi nhưng một nghiên cứu tổng quan hệ thống đã nhận ra mối liên hệ giữa alen A của gen rs9939609 của gen FTO với tình trạng thừa cân ở trẻ dưới 2,5 tuổi. Mỗi phiên bản copy của alen $A$ sẽ làm tăng khoảng $2,4 \%$ nguy cơ thừa cân béo phì. Ảnh hưởng của đa hình nucleotide của gen FTO lên chỉ số BMI chỉ ở mức độ trung bình, với những người đồng hợp tử alen nguy cơ sẽ nặng hơn khoảng $3 \mathrm{~kg}$ so với những người đồng hợp tử alen bảo vệ [5].

Dữ liệu từ nhiều nghiên cứu đã cho thấy mối liên quan chặt chẽ giữa khối mõ hoặc chỉ số BMI với tình trạng đa hình nucleotide ở gen FTO cả ở đối tượng trẻ em và người trưởng thành. Mối liên hệ giữa gen FTO và chỉ số BMI được nghiên cứu trền 13 quần thể với hơn 38.000 đổi tượng. $16 \%$ số người trưởng thành có mang gen đồng hợp tử với dạng đa hình nucleotide này và có nguy cơ thừa cân tăng 1,67 lần, tức là họ năng hơn khoảng $3 \mathrm{~kg}$ so với những người không mang gen này. Một dạng đa hình khác là rs121980 ở đoạn introns đầu tiên trên gen FTO cũng có liên quan đến tình trạng béo phì ở người trưởng thành $(O R=1,55)$ trên cộng đồng người Pháp. Ba nghiên cứu khác trên trẻ em và người trưởng thành cũng cho thấy mối liên quan chặt chẽ giữa tính đa hình nucleotide của gen FTO với tình trạng thừa cân béo phì. Các đa hình nucleotide có liên quan chặt chẽ nhất bao gồm rs17817449, rs3751812, và rs1421085. Đa hình nucleotide của gen FTO có liên quan chặt chẽ với bệnh tiểu 
đường type-2 nhưng cũng có liên quan chặt chẽ với việc tăng chỉ số BMI, vì thế, mối liên quan giữa gen FTO với bệnh biểu đường type-2 đã được loại bỏ bởi nguy cơ tiểu đường tăng lên là do tăng BMI. Các tài liệu gần đây gợi ý rằng, chỉ có $1-2 \%$ sự biến động của cân nặng được giải thích do gen (ví dụ như gen FTO và gen MCR4).

\section{*Gen BDNF}

Tên đây đư: brain derived neurotrophic factor (còn biết dưới tên ANON2; BULN2). Vị trí: 11p14.1

Vai trò của gen BDNF trong việc điều hoà cơ chế hấp thu thực phẩm và cơ chế ức chễ cảm giác ngon miệng, giảm cân đã được nghiên cứu từ trước. Nghiên cứu trên mô hình động vật gợi ý rằng gen $\mathrm{BDNF}$ đóng vai trò rất quan trọng trong việc cân bằng năng lượng. Trên chuoọt, thiếu hụt đơn bội ở gen BDNF sẽ dẫn đến béo phì. Chuột có gen BDNF không hoạt động ở trạng thái dị hợp tử sẽ giảm $50 \%$ biểu hiện BDNF ở vùng dưới đồi, những con chuột này cũng sẽ mắc phải chứng ăn nhiêu, thừa cân. Tình trạng này sẽ bị đảo ngược lại khi BDNF được truyền vào não thất.

Mặc dù các nghiên cứu trên chuột ủng hộ vai trò của BDNF trong việc giữ cân bằng năng lượng, nhưng dữ liệu từ các nghiên cứu trên người là rất ít. Một số nghiên cứu đã chứng minh rằng có mối liên quan ngược chiều giữa lượng BDNF ở vùng ngoài vi và chỉ số khối cơ thể BMI ở trẻ em và người trưởng thành. Một SNPs phổ biến của gen BDNF là Val66Met, đã được rất nhiều nghiên cứu chứng minh có thể làm thay đổi cân nặng của cơ thể.

Nghiên cứu của Hong và cộng sự trên 20.270 người Hàn Quốc cũng cho thây mối liên quan giữa đa hình này của gen BDNF với chỉ số BMI, tuy nhiên, ảnh hưởng của đa hình Val66Met lên BMI cộng đồng người Hàn QQuốc nhỏ hơn so với trên cộng đồng người châu Âu. Các đa hình khác của gen BNDF bao gồm (rs925946, -13 kb của đa hình rs6265) và (rs492346, $-23 \mathrm{~kb}$ của đa hình rs6265) cũng đã được các nghiên cứu trên người Trung Quốc, Nhật Bản và Phillipine và chứng minh được các mối liên quan đến chỉ số BMI.

\section{GEN VÀ BỆNH UNG THU' \\ *Gen MSH2}

Tên đầy đủ: MutS homolog 2 (còn được biết dưới tên FCC1; COCA1; HNPCC; LCFS2; hMSH2; HNPCC1; MMRCS2). Vị trí: nằm trên NST số 2 ở vị trí 2p21-p16.3.

Nam giới và phụ nữ có đột biến ở MSH2 có $52-82 \%$ nguy cơ suốt đời (đến 70 tuổi) phát triển ung thư đại tràng hoặc trực tràng. Hơn nữa, hội chứng này có liên quan đến $30 \%$ nguy cơ ung thư đại tràng hoặc trực tràng thứ hai xuất hiện trong vòng 10 năm kể từ khi ung thư đại tràng đầu tiên được phát hiện. Điều quan trơng cần lưu ý là nguy cơ ung thư đại trực tràng vấn cao hơn sau 70 tuổi [6]

Theo các nghiên cứu, 25\% bệnh nhân mắc ung thư đại trực tràng có tiền sử gia đình từng mắc bệnh. Thường gặp nhất trong số này là hội chứng Lynch (còn gọi là ung thư đại trực tràng không polyp di truyền - HNPCC) chiếm khoảng 5$8 \%$ tất cả các loại ung thư đại trực tràng và thường liên quan đến đột biến dòng mầm trong các gen do quá trình sửa chữa bắt cặp nhầm gây ra, bao gồm các gen như: MSH2, MSH6, MLH1, PMS1, PMS2. Những cá nhân gặp phải đột biến dòng mầm trong các gen được coi là chiếm ưu thế gây ra bệnh có tới $80 \%$ nguy cơ phát triển ung thư đại trực tràng. Bên cạnh đó, nghiên cứu của Liu và các cộng sự trên 48 đối tượng ung thư đại trực tràng đã xác định các đột biến trong quá trình sửa chữa các gen bao gồm:

- 31\% đột biến ở gen MSH2

- 33\% đột biến ở gen MLH1

- 2\% đột biến ở gen PMS1

- 4\% đột biến ở gen PMS2

\section{*Gen BRCA1}

Tên đây đủ: BRCA1 DNA repair associated (còn biết dưới tên IRIS; PSCP; BRCAI; BRCC1; FANCS; PNCA4; RNF53; BROVCA1; PPP1R53). Vị trí: nằm ở NST số 17 , vị trí 17q21.31.

BRCA1 là một gen nhạy cảm với ung thư vú lần đầu tiên được xác định vào năm 1994. Những người mang đột biến (bất thường) trong gen này có nguy cơ cao bị ung thư vú hoặc ung thư buồng trứng. Gen BRCA1 bình thường có vai trò sửa chữa các điểm đứt gãy trong DNA. Tuy nhiên, khi gen bị đột biến, người ta cho rằng chức năng sửa chữa này có thể bị vô hiệu hóa, do đó dẫn đến nhiều lỗi sao chép DNA và phát triển ung thư. Các đột biến trong gen này là nguyên nhân gây ra khoảng $40 \%$ trường hợp ung thư vú di truyền và hơn $80 \%$ trường hợp ung thư vú và buồng trứng di truyền [7].

\section{*Gen BRCA2}

Tên đầy đư: BRCA2 DNA repair associated (còn biết dưới tên FAD; FACD; FAD1; GLM3; BRCC2; FANCD; PNCA2; FANCD1; XRCC11; BROVCA2). Vị trí: NST số 13 tại vị trí 13q12.3.

BRCA2 là một gen ức chế khối u. Các đột biến trong gen này sẽ làm tăng nguy cơ ung thư vú và ung thư buồng trứng. Gen này mã hóa một protein hạt nhân lớn, là một thành phần thiết yếu của con đường sửa chữa DNA, ngăn chặn sự 
hình thành của sự sắp xếp lại tổng thể NST.

Các đột biến di truyền ở BRCA1 và BRCA2, làm tăng nguy cơ phát triển ung thư vú hoặc ung thư buồng trứng suốt đời. Cả BRCA1 và BRCA2 đều tham gia vào việc duy trì sự ổn định của bộ gen, cụ thể là con đường tái tổ hợp tương đồng để sửa chữa DNA sợi đôi.

Gen BRCA1 và BRCA2 đôi khi được gọi là các gen ức chế khối u bởi khi các gen này biến thể theo hướng có hại thì tình trạng ung thư sẽ bắt đầu phát triển. Tại Mỹ, có khoảng $12 \%$ số phụ nữ sẽ bị ung thư vú vào một thời điểm nào đó trong đời. Tuy nhiên, nếu phụ nữ thừa hưởng gen BRCA1 biến thể có hại thì nguy cơ sẽ tăng lên $55-72 \%$ và sẽ tăng lên $45-69 \%$ nếu thừa hưởng biến thể có hại của gen BRCA2.

Cũng giống như những phụ nữ bị ung thư vú do các yếu tố khác, nhưng phụ nữ có biến thể có hại của gen BRCA1 và BRCA2 cũng sẽ tăng nguy cơ ung thư vú ở bên vú đối diên sau khi được chẩn đoán ung thư vú ở một bên. Nguy cơ ung thư vú ở bên đối diện sẽ tăng lên kể từ khi được chẩn đoán ung thư vú ở bên ban đầu, và sẽ đạt khoảng $20-30 \%$ sau 10 năm và khoảng $40-50 \%$ sau ít nhất 20 năm, phụ thuộc vào liều gen.

Phụ nữ mang biến thể có hại của gen BRCA1 và BRCA2 cũng sẽ bị tăng nguy cơ ung thư cổ tử cung. Nguy cơ sẽ tăng 39-44\% nếu mang biến thể có hại của gen BRCA1 và tăng $11-17 \%$ nếu mang biển thể có hại của gen BRCA2, trong khi đó, tỷ lệ mắc ung thư thông thường ở phụ nữ là $1,2 \%$ [8].

\section{KẾT LUÂ̂N}

Gen và các yếu tố về di truyền đóng một vai trò quan trọng trong việc biểu hiện kiểu hình về sức khỏe, vóc dáng, và nguy cơ mắc các bệnh chuyển hóa. Các nghiên cứu khoa học đã chứng minh, đột biến của một số gen có liên quan mât thiết đến một số vấn đề về các bệnh chuyển hóa, và sâu hơn nữa là có liên quan mật thiết đến dinh dương như khả năng dung nạp chất béo, nguy cơ thừa cân béo phì cũng như khả năng giảm cân... Việc triển khai và áp dụng xét nghiệm về gen trong đời sống (như xét nghiệm gen của CircleDNA) nhằm phát hiện ra mức độ nguy cơ của các gen bất thường có khả năng gây bệnh, hoặc tiềm năng di truyền có ý nghĩa trong định hướng phòng, điêu trị bệnh.

\section{TÀI LIÊU THAM KHẢO}

1. Tong, Y., et al., Association between TCF7L2 gene polymorphisms and susceptibility to type 2 diabetes mellitus: a large Human Genome Epidemiology (HuGE) review and meta-analysis. BMC Med Genet, 2009. 10: p. 15.

2. Gohlke, H., et al., SLC30A8 (ZnT8) Polymorphism is Associated with Young Age at Type 1 Diabetes Onset. Rev Diabet Stud, 2008. 5(1): p. 25-7.

3. Chang, W.C., et al., LDLR-mediated lipidometranscriptome reprogramming in cisplatin insensitivity. Endocr Relat Cancer, 2020. 27(2): p. 81-95.

4. Li $\mathbf{Z}$, et al., Polymorphisms in PCSK9, LDLR, BCMO1, SLC12A3, and KCNJ1 are Associated with Serum Lipid Profile in Chinese Han Population. Int J Environ Res Public Health., 2019. 16(17).

5. Hess, M.E. and J.C. Bruning, The fat mass and obesity-associated (FTO) gene: Obesity and beyond? Biochim Biophys Acta, 2014. 1842(10): p. 2039-47.

6. Baumert, $\mathbf{P}_{\text {., }}$ et al., Genetic variation and exercise-induced muscle damage: implications for athletic performance, injury and ageing. Eur J Appl Physiol, 2016. 116(9): p. 1595-625.

7. Boyajyan, A.S., S.A. Atshemyan, and R.V. Zakharyan, [Association of schizophrenia with variations in genes encoding transcription factors]. Mol Biol (Mosk), 2015. 49(6): p. 977-83.

8. Anastasiadi, Z., et al., Breast cancer in young women: an overview. Updates Surg, 2017. 69(3): p. 313-317.

\section{KIẾN THỨC VỀ CHĂM SÓC NGƯờI BÊNH ĐÁI THÁO ĐƯờNG TÍP 2 CỦA NGƯỜI CHĂM SÓC CHÍNH TẠI HAI HUỴ̂̂̉N CỦA TỈNH THÁI BÌNH NĂM 2019} Nguyễn Việt Khánh ${ }^{1}$, Lương Đức Sơn ${ }^{2}$, Nguyễn Đức Thanh ${ }^{1}$

TÓM TẮT.

Nghiên cứu mô tả kiến thức về chăm sóc người

${ }^{1}$ Trường Đại học Y Dược Thái Bình

'Sở Y tế Thái Binh

Chịu trách nhiệm chính: Nguyễn Đức Thanh

Email: bsthanh@hotmail.com

Ngày nhận bài: 18.10 .2021

Ngày phản biện khoa học: 20.12.2021

Ngày duyệt bài: 30.12.2021 bệnh đái tháo đường típ 2 của người chăm sóc chính cho người bênh. Đề tài áp dụng phương pháp nghiên cứu định lượng qua phỏng vấn 1.238 đối tượng là người chăm sóc chính cho người bênh đái tháo đường típ 2 tại hai huyện của tỉnh Thái Bình năm 2019. Kết quả: Người chăm sóc chiếm nhiều nhất là có trình độ học vấn tốt nghiệp trung học cơ sở $(38,8 \%)$, phần lớn là con $(53,8 \%)$, hoặc vớ/chồng $(39,0 \%)$ của người được chăm sóc. Trong số 7 nội dung chăm sóc được đánh giá, chế độ dinh dưỡng được đối tượng biết đển với điểm trung bình cao nhất $(2,74 \pm 0,85)$, tiếp đến là 